\title{
CROSS-BORDER CONVERSIONS IN THE EUROPEAN UNION AFTER THE POLBUD CASE
}

\author{
IRYNA BASOVA*
}

\begin{abstract}
Cross-border conversions may be considered as an achievement of the Court of Justice of the European Union (CJEU, Court) since its case law paves the way towards acceptance of such cross-border operations in all Member States. In the Polbud case, the CJEU clarified the scope of the freedom of establishment in regard to cross-border conversions. That judgement should give an impulse to those Member States whose law remains silent on the issue, lacks regulation or is not in line with the provisions on the freedom of establishment, to take appropriate legislative measures. However, a creation of a legal framework at the European level is still needed to provide a commonly-accepted procedure for such operations, to secure protection for vulnerable constituencies of a company, to prevent abusive practices and to regulate cooperation between the states which are involved in cross-border conversions.
\end{abstract}

\section{INTRODUCTION}

A cross-border conversion is an operation of transnational nature through which a company may change the governing law of one Member State to another. Considering that EU law does not have a harmonised legal framework for cross-border conversions, they are regulated by the national laws of the Member States. ${ }^{1}$

Some Member States are reluctant to allow cross-border conversions in their jurisdictions because in comparison with a primary incorporation, when a company only starts functioning, a conversion is a transformation of an already existing company with debts, liability, obligations which such company may seek to circumvent. On the one hand, a cross-border conversion facilitates migration of companies within the EU, which is welcomed at the European level, but on the other, a change in the governing law poses risks of abusive practices and may adversely affect the interests of company's constituencies, including minority shareholders, employees and creditors. ${ }^{2}$ Such possible negative outcomes may result in different treatment of

\footnotetext{
* LL.M in European Business Law at Lund University. The article builds on the author's master thesis carried out at Lund University in 2018. Contact: irynabasova@gmail.com.

1 Policy Department for Citizens' Rights and Constitutional Affairs, 'Cross-Border Transfer of Company Seats' PE 583.143, 1-2.

< http://www.europarl.europa.eu/RegData/etudes/BRIE/2017/583143/IPOL BRI(2017)583143 E N.pdf $>$ accessed 16 July 2018.

${ }^{2}$ On detailed analysis of possible risks see T Biermeyer, 'Chapter 6: Empirical Data on Risks of Stakeholders in Cross-Border Seat Transfers. Stakeholder Protection in Cross-Border Seat Transfers in the EU' (WLP, 2015), 207-227 < https://ssrn.com/abstract=2747129> accessed 12 July 2018; C Cathiard, European Added Value Assessment on a Directive on the cross-border transfer of company seats (14th company law Directive)', ANNEX I Legal effects of the requested legislative instrument' (2012), 72-76.

<http://www.europarl.europa.eu/RegData/etudes/etudes/join/2013/494460/IPOLJOIN_ET(2013)494460(ANN01)_EN.pdf> accessed 12 July 2018.
} 
cross-border conversions by the Member States. Due to the absence of a uniform legal framework for cross-border conversions at the European level, divergence in the domestic corporate laws and different theories which the Member States follow the status of such transactions is lacking clarity. However, the judgment of the CJEU in the Polbud case $^{3}$ contributes to the development of the concept of cross-border conversions. It clarifies the scope of the freedom of establishment in regard to crossborder conversions that affects the competence of the Member States in this area and strengthens the status of such operations in the EU.

This article is focused on an analysis of the status of cross-border conversions in the EU after the CJEU handed down its judgement in the Polbud case. It contains an analysis on how the freedom of establishment interacts with the reserved area and discretion of the Members States regarding companies when cross-border conversions are at stake.

The first part is focused on the concept of a cross-border conversion and its integral features. Then the article discusses how the CJEU interprets the provisions on the freedom of establishment regarding outbound and inbound stages of a crossborder conversion. In this regard it should be mentioned that a cross-border conversion presupposes consecutive application of the national laws of the home and the host state ${ }^{4}$ and its successful consummation depends on both legal regimes. ${ }^{5}$ An operation results in interaction with two states, the home state which a company intends to leave and the host state, which a company intends to enter. Therefore, a cross-border conversion includes two steps: an exit/move out from the home state and a move in/enter the host state where the conversion occurs. The competence of the Member States in regard to cross-border conversions differs and depends on whether a company leaves (outbound step) or enters (inbound step) their territory. Accordingly, both steps are considered separately. The final part of the article contains a brief description of how cross-border conversions are treated at national levels and possible obstacles to successful consummation of such operations.

\section{THE CONCEPT OF CROSS-BORDER CONVERSIONS}

One should distinguish the ability to choose a country where to incorporate a company (primary incorporation) and to obtain a legal personality from the ability to move to any other country during company's life (reincorporation), where the legal personality is preserved, but the governing law to which a company is subject, is changed. The first scenario is the 'birth' (creation) of a company in one Member State, whilst the second scenario is a transformation of an existing company within a different

\footnotetext{
3 The case concerns a conflict between a company, incorporated in Poland, Polbud, which transferred its registered office to Luxembourg with intent to change the applicable law to Luxembourg law, and Poland which agreed to remove the company from the register if documents on liquidation are provided, see Case C-106/16 Polbud - Wykonawstwo [2017] EU:C:2017:804.

${ }^{4}$ Case C-378/10 VALE Épitési [2012] EU:C:2012:440, para 44.

${ }^{5}$ Case C-106/16 Polbud - Wykonawstwo [2017] EU:C:2017:804, Opinion of Advocate General Kokott, para 23.
} 
Member State. A cross-border conversion relates to the last scenario since a company can be converted only when it already exists.

A cross-border conversion is an operation through which a company, formed in one Member State is converted into a company governed by the law of another Member State. ${ }^{6}$ In other words, a company, duly established in one Member State (the home state), moves to another Member State (the host state), where it is converted in one of the available forms of legal entity under the legal regime of the host state. An interesting point was raised by Advocate General (AG) Jääskinen in the Vale case: a transformation of a company into a company of the same type in the host state (for instance, a limited liability company) is not a conversion, but rather a 'cross-border reincorporation.7 However, the CJEU disagreed and applied the term of cross-border conversion, which seems to be more appropriate. The company laws of the Member States vary significantly and therefore limited liability companies or joint stock companies in the home state are not the same as in the host state. ${ }^{8}$

The features of cross-border conversions may be defined as an accumulation of the following: a transfer of a company's seat that is a connecting factor in the host state; a reincorporation in the host state through a conversion as described above; a change in the law which governs a company; a retention of legal personality; and the absence of liquidation. ${ }^{9}$ The cornerstone of a cross-border conversion is the retention of legal personality, which means that a company does not have to undergo a liquidation procedure. Thus, assets are not distributed, liabilities and contractual relations remain unaffected. ${ }^{10}$ In this sense, a conversion is the opposite of liquidation, the latter which presupposes termination of activities, payment and recovery of debts, carrying out other duties, sale, distribution of the assets which are left after satisfying the demands of creditors, closing accounts in banks, deposit of documents and other

${ }^{6}$ Case C-378/10 VALE (n 4), para 23; Opinion of Advocate General Kokott (n 5), para 22; Case C106/16 Polbud (n 3), para 33.

In a Proposal for a Directive amending Directive (EU) 2017/1132 as regards cross-border conversions, mergers and divisions it is defined as 'an operation whereby a company, without being dissolved, wound up or going into liquidation, converts the legal form under which it is registered in a departure Member State into a legal form of a company of a destination Member State and transfers at least its registered office into the destination Member State whilst retaining its legal personality'. See European Commission, 'Proposal for a Directive of the European Parliament and of the Council amending Directive (EU) 2017/1132 as regards cross-border conversions, mergers and divisions’ COM (2018) 241 of 25 April 2018 (Proposal for a Directive), art 86b (2).

${ }^{7}$ Case C-378/10 VALE Épitési [2012] EU:C:2012:440, Opinion of AG Jääskinen, paras 33-34.

${ }^{8}$ By analogy with M Szydlo, 'The Right of Companies to Cross-Border Conversion under the TFEU Rules on Freedom of Establishment' (2010) 7 European Company and Financial Law Review 414, 437-438.

9 European Commission, 'Study on the Law Applicable to Companies' (2016) (Study on the law applicable to companies), $215<$ https://publications.europa.eu/en/publication-detail/-

/publication/259a1dae-1a8c-11e7-808e-01aa75ed71a1/language-en> accessed 11 July 2018 (applied term is a reincorporation); C Gerner-Beuerle, F Mucciarelli, E Schuster, M Siems, 'Cross-border Reincorporations in the European Union: The Case for Comprehensive Harmonisation' (2018) 18 Journal of Corporate Law Studies 1, 3-4 (a term of reincorporation is used); F Stoica, 'Recent Developments regarding Corporate Mobility within EU's Internal Market' (2016), 8

$<$ https://papers.ssrn.com/sol3/papers.cfm?abstract_id=2783809> accessed 11 July 2018; M Szydlo (n 8) 415.

${ }^{10}$ European Parliament resolution with recommendations to the Commission on the cross-border transfer of the registered office of a company (2008/2196(INI)) of 10 March 2009 (European Parliament resolution (2008/2196(INI)), Recommendation 1. 
actions which are required by the applicable national law. This would not make much sense in the case of cross-border conversion, where the nature of the operation is different. If, in a cross-border conversion, a company is subject to liquidation, an operation becomes pointless since there is nothing to convert anymore. ${ }^{11}$ It is, moreover important to understand who the beneficiaries of the freedom of establishment are. In the case of a liquidation, ex-shareholders, which are individuals or legal entities, but not the company itself, benefit from the freedom of establishment in the host state. ${ }^{12}$ In this sense, the operation is not a company's conversion in the host state, but rather a formation of a new company in another jurisdiction by the former shareholders. ${ }^{13}$ To be honest, shareholders do not need to liquidate a company in order to form a new one in another jurisdiction. If prior liquidation is required, a company will be deprived of the right to convert itself in the host state. This since, after liquidation, it ceases to exist. Such a scenario contradicts the nature of crossborder conversion.

Another feature of cross-border conversions is the transfer of the seat, which is the connecting factor in the host state. For a company to be allowed to convert itself in another state, the transfer of its seat to that state is a prerequisite for the operation. A cross-border conversion is the result which a company may seek to achieve, whilst the seat transfer is the means to obtain that result. However, what one should bear in mind is that there is no uniform scenario for achieving that result. The Member States have their own rules, including the requirement on connecting factors, which are necessary for a company to obtain and subsequently maintain the status of a domestic company. Usually a conversion presupposes the transfer of the registered office, however, in some jurisdictions the transfer of the real seat is a precondition for a conversion as well. ${ }^{14}$ Therefore, a cross-border conversion entails a 'legal mobility' which is conducted through the transfer of the registered office; which may be combined with a 'physical mobility' via the relocation of the real seat to the host state. ${ }^{15}$ Prior to the Court's judgement in the Polbud case, it was unsettled whether a crossborder conversion which is conducted solely through the transfer of the registered

\footnotetext{
${ }^{11}$ F Mucciarelli, 'Company 'Emigration' and EC Freedom of Establishment: Daily Mail Revisited' (2008) 9 European Business Organization Law Review 267, 297-298; M Szydlo (n 8), 438.

12 ibid.

13 ibid.

${ }^{14}$ C Gerner-Beuerle, F Mucciarelli, E Schuster, M Siems (n 9), 4-5;

It is interesting that the transfer of the statutory seat does not necessarily trigger a change of the applicable law in some Member States, such as Italy and Czech Republic. See Study on the law applicable to companies (n 9), 239; T Biermeyer, 'Chapter 4: Current Regulation of Cross-Border Transfers of the Registered Office at the Domestic and European Level. Stakeholder Protection in Cross-Border Seat Transfers in the EU' (WLP, 2015), 96, 108-109

$<$ https://ssrn.com/abstract $=2747105>$ accessed 13 July 2018; It means that a company which located its statutory seat in the host state remains to be subject to the law of the home state. Such option was considered by the Commission. However, it was recognised that a change in the law as a result of the seat transfer is a better option due to legal certainty, legal complexity, supervision and control. See Commission Staff Working Document 'Impact assessment on the Directive on the crossborder transfer of registered office' SEC (2007) 1707 (Impact assessment 2007), 45-46

$<$ http://ec.europa.eu/internal_market/company/docs/shareholders/ia_transfer_122007_part1_en.p df $>$ accessed 16 July 2018.

15 O Mörsdorf, 'The Legal Mobility of Companies within the European Union through Cross-Border Conversion' (2012) 49 Common Market Law Review 629, 630.
} 
office (legal mobility), falls within the scope of the freedom of establishment that resulted in different positions. ${ }^{16}$ The clarification of the Court is crucial, since if the freedom of establishment does not apply, the Member States enjoy full autonomy in when governing such operations.

The judgement of the Court in the Polbud case differs from the conclusions made by AG Kokott, ${ }^{17}$ as well as several Member States. Poland and Austria submitted that the freedom of establishment cannot apply to the sole transfer of the registered office, since it does not necessarily imply the carrying out of economic activity in the host Member State. ${ }^{18}$ AG Kokott concluded that the freedom of establishment:

'applies to an operation whereby a company incorporated under the law of one Member State transfers its statutory seat to another Member State with the aim of converting itself into a company governed by the law of the latter Member State, in so far as that company actually establishes itself in the other Member State, or intends to do so, for the purpose of pursuing genuine economic activity there. ${ }^{19}$

The CJEU disagreed with this view and looked at the situation from a different angle. It pointed out that a company, formed in one of the Member States and having the registered office, the central administration or the principal place of business in the $\mathrm{EU}$, in principle, may benefit from the freedom of establishment. ${ }^{20}$ The freedom of

${ }^{16}$ See C Gerner-Beuerle, F Mucciarelli, E Schuster, M Siems (n 9), 1-2; S Rammeloo, 'Case C-378/10 VALE Épitési Kft., Judgment of 12 July 2012, Not Yet Reported Freedom of Establishment: CrossBorder Transfer of Company 'Seat' - The Last Piece of the Puzzle?' (2012) 19 Maastricht Journal of European and Comparative Law 563, 582-583, 588; A Baert, 'Crossing Borders: Exploring the Need for a Fourteenth EU Company Law Directive on the Transfer of the Registered Office' (2015) 26 European Business Law Review 581, 599-600; O Mörsdorf (n 15), 637-649, 670; T Biermeyer, 'Chapter 3: The Impact of European Law on Cross-Border Seat Transfers. Stakeholder Protection in Cross-Border Seat Transfers in the EU' (WLP, 2015) 67-70, 72, 90-91

$<$ https://ssrn.com/abstract=2747103> accessed 16 July 2018; T Biermeyer, 'Shaping the Space of Cross-Border Conversions in the EU. Between Right and Autonomy: VALE' (2013) 50 Common Market Law Review 571, 586-589; W Schon, 'The Mobility of Compromise in Europe and the Organizational Freedom of Company Founders' (2006) 3 European Company and Financial Law Review 122, 139; F Mucciarelli, 'The Function of Corporate Law and the Effects of Reincorporations in the U.S. and the EU' (2012) 20 Tulane Journal of International and Comparative Law 421, 432-433; J Meeusen, 'Freedom of Establishment, Conflict of Laws and the Transfer of a Company's Registered Office: Towards Full Cross-Border Corporate Mobility in the Internal Market?' (2017) 13 Journal of Private International Law 294, 294-323; 'Cross-Border Transfer of Company Seat within the European Union' 4-7, 11-12 (4th Congress of the notaries of Europe, 5-7 October 2017) <https://www.notariesofeurope-congress2017.eu/en/media-library/> accessed 16 July 2018; M Szydlo (n 8), 423-424; Policy Department for Citizens' Rights and Constitutional Affairs 'CrossBorder Mergers and Divisions, Transfers of Seat: Is There a Need to Legislate?’ (2016), 35 <http://www.europarl.europa.eu/thinktank/en/document.html?reference=IPOL_STU(2016)556960 $>$ accessed 13 July 2018.

17 Opinion of AG Kokott (n 5), paras 32-43, 67.

18 Case C-106/16 Polbud (n 3), para 30.

19 Opinion of AG Kokott (n 5) para 43 (emphasis added). The analysis was based on the concept of establishment, elaborated by the CJEU, that presupposes actual establishment in the host state and carrying out genuine economic activity in that state. She also pointed out that the freedom of establishment grants 'economic operators in the European Union the right to choose the location of their economic activity, it does not give them the right to choose the law applicable to them'. See paras 32-38, 43, 67.

${ }^{20}$ Case C-106/16 Polbud (n 3), para 32. 
establishment presupposes that companies have the right to set up and manage companies in the host Member State under the conditions laid down for domestic companies in the national law of that state. ${ }^{21}$ Therefore, it encompasses the right of a company to conduct a cross-border conversion, provided that all required conditions for reincorporation are met in the host state, in particular, the test on connecting factors. ${ }^{22}$ The CJEU then explained a cross-border conversion in the Polbud case by analogy with the Centros case. ${ }^{23}$ A cross-border conversion through the transfer of the registered office may fall within the scope of the freedom of establishment (regardless of the fact that business is to be conducted in the home state) if that company complies with the test on connecting factors of the host state. ${ }^{24}$ The possibility of a cross-border conversion through the transfer of the registered office depends on the test on connecting factors, which is determined by the host state. Such a test depends on the theory upon which the national system is founded, such as the incorporation theory, the theory of real seat or the mixed theory. The definition of what constitutes connecting factors (which serve as a link between a company and the national legal order) is a reserved area of the host state. ${ }^{25}$ Thus, a cross-border conversion is possible through the transfer of the registered office only if it is allowed under the law of that state. However, the situation will be different if the real seat is the connecting factor as well in the host state.

\section{MOVE OUT (OUTBOUND) STEP OF CROSS-BORDER CONVERSIONS}

The status of a cross-border conversion depends on the rules of the Member States, who remain competent to regulate such operations. Therefore, it is necessary to understand which powers the Member States have been afforded by the CJEU under the freedom of establishment. In other words, what the home states are allowed to require; what type of measures that are prohibited; and, in particular, whether the home state has to permit a company to leave its jurisdiction for the purpose of conversion in another legal order within the EU without liquidation. ${ }^{26}$

In the present state of EU law companies are creatures of the national laws, which determine their incorporation and functioning. ${ }^{27}$ It is for the Member States to decide which connecting factor should be required in order to obtain and maintain the company's legal personality within its jurisdiction. ${ }^{28}$ Since the Member States have that

\footnotetext{
21 ibid para 33.

22 ibid.

${ }^{23}$ Case C-106/16 Polbud (n 3), para 38; In the Centros case the CJEU confirmed the right of a company, incorporated in one Member State and having the registered office there, to establish itself in another Member State, despite the fact that the purpose of incorporation in the first Member State was not conducting business there. See Case C-212/97 Centros Ltd v Erbvervs- og Selskabsstyrelsen [1999] ECR I-1459.

${ }^{24}$ Case C-106/16 Polbud (n 3), paras 38, 41, 43, 44.

25 Case 81/87 The Queen v Treasury and Commissioners of Inland Revenue, ex parte Daily Mail and General Trust PLC [1988] ECR-5483, para 21; Case C-106/16 Polbud (n 3), paras 33, 34.

${ }^{26}$ Study on the law applicable to companies (n 9), 217; C Gerner-Beuerle, F Mucciarelli, E Schuster, M Siems (n 9), 8.

${ }_{27}$ Case 81/87 Daily Mail (n 25), para 19.

28 As examples, see Case C-210/06 Cartesio Oktató és Szolgáltató bt [2008] ECR I-09641, para 110; Case C-378/10 VALE (n 4), para 29; Case C-106/16 Polbud (n 3), para 43.
} 
power, the question arises of how the home state should treat cross-border conversions which are conducted through the transfer of the company's seat, which is the connecting factor in that state. In the Cartesio case, ${ }^{29}$ the CJEU considered two scenarios, depending on whether there is a change in the law applicable to the company. ${ }^{30}$ In the first scenario, where a company, formed in one Member State, moves its seat to another Member State, but there is no change in the applicable law, the home state has the power to block a cross-border transfer. ${ }^{31}$ However, the situation is different in the second scenario. If the transfer of the company's seat leads to a change in the applicable law, that company is converted into a form of company in the host state (the law of which is henceforth applicable to that company). ${ }^{32}$ Here, since the conversion in another jurisdiction leads to obtaining the status of a domestic company under the law of the host state, the home state losses the possibility to require the winding-up or liquidation of a company. ${ }^{33}$ This since such a requirement would prevent the company from a cross-border conversion in the host state, and therefore, constitute a restriction on the freedom of establishment. ${ }^{34}$ In the Polbud case the CJEU confirmed that in cross-border conversions, the right of the Member States to determine connecting factors does not mean that the law of the home state on formation and winding up of companies enjoys immunity from the provisions on the freedom of establishment. ${ }^{35}$ The home state does not have the right to impose conditions for cross-border conversions that are more restrictive than for those applying to conversions of a domestic nature. ${ }^{36}$ In case of cross-border conversions all requirements of the home state should be in line with the provisions on the freedom of establishment. The requirement to liquidate the company before it can be removed from the register in the home state constitutes a restriction on the freedom of establishment since it is liable to impede, if not prevent, the cross-border conversion'. ${ }^{37}$ All other measures of the home state are considered to be restrictions on the freedom of establishment as well if they 'prohibit, impede or render less attractive' cross-border conversions. ${ }^{38}$

National measures which restrict the freedom of establishment may, nonetheless, be acceptable if they are justified. Measures may be justified on the basis of public policy, public security or public health ${ }^{39}$ on the one hand, or by overriding reasons in the public interests on the other, including the protection of the interests of

29 The case concerns a conflict between a domestic entity, Cartesio, which transferred its seat from Hungary to Italy, and Hungary, a state, where Cartesio was incorporated. Hungary rejected to enter the amendment in new address of the company in commercial register due to prohibition of seat transfer of Hungarian company to another Member State while keeping Hungarian 'nationality'. Case C-210/06 Cartesio (n 28).

30 ibid para 111.

31 ibid paras $110-111$.

32 ibid para 111.

${ }^{33}$ Unless it is justified; ibid paras 111-113.

34 ibid paras 112-113.

${ }^{35}$ Case C-106/16 Polbud (n 3), para 43.

${ }^{36}$ ibid.

37 ibid paras 45-51.

38 ibid, para 46.

${ }^{39}$ Consolidated Version of the Treaty on the Functioning of the European Union [2016] OJ C 202/47, art 52(1). 
employees, creditors and minority shareholders. ${ }^{40}$ The Member States are allowed to ensure that cross-border conversions do not affect public interests inappropriately. ${ }^{41}$ In this regard, and in particular, the restrictive measures may be justified by the protection of the interests of employees, creditors and minority shareholders, provided that they 'are appropriate for ensuring the attainment of the objective in question and not go beyond what is necessary to attain that objective, ${ }^{42}$ In this respect, a general prohibition of cross-border conversions is disproportionate since not all cross-border transactions might threaten public interests protected in the Member States. ${ }^{43}$ Equally, a requirement of mandatory liquidation applied in a general manner to all companies intending to move to another jurisdiction for the purposes of conversion, cannot be justified since it goes beyond what is necessary to achieve the objective of protecting public interests. ${ }^{44}$ Justification is a very peculiar stage which requires an analysis of measures on a case-by-case basis. The Member State needs to consider the actual threat which an operation may cause and if it is possible to adopt less restrictive measures for ensuring the attainment of the objective pursued. ${ }^{45}$

In summary, a change of the applicable law defines the boundaries of the competence of the home state in relation to a company. Since a conversion presupposes a change in the governing law, the home state loses the absolute power over that company and cannot prevent it from migration to another jurisdiction. ${ }^{46}$ Companies are creatures of the national laws which govern their functioning as well as the connecting factors required for obtaining and maintaining the company's legal status. However, this reserved area is not excluded from the provisions on the freedom of establishment when a cross-border conversion is at stake. National measures which restrict the freedom of establishment may only be accepted if they are justified.

\section{MOVE IN (INBOUND) STEP OF CROSS-BORDER CONVERSIONS}

The inbound step of a cross-border conversion concerns an interaction between the host state and a foreign company which intends to convert itself there. In its judgment in Cartesio, the CJEU held that the home state cannot prevent a company

\footnotetext{
${ }^{40}$ However, the Member States may rely on other public (general) interests as well. Measures should fulfil the following conditions: be justified by overriding reasons in the public interest (imperative requirements in the general interest), be applied in a non-discriminatory manner, be suitable for achievement of objective they pursue, and not go beyond what is necessary in order to attain it. As examples, see Case C-55/94 Reinhard Gebhard v Consiglio dell'Ordine degli Avvocati e Procuratori di Milano [1995] ECR I-4165, para 37; Case C-212/97 Centros (n 23), para 34; Case C-167/01 Kamer van Koophandel en Fabrieken voor Amsterdam v Inspire Art Ltd. [2003] ECR I-10155, paras 132, 133; Case C411/03 SEVIC Systems AG. [2005] ECR I-10805, paras 28-29; Case C-378/10 VALE (n 4), para 39; Case C-106/16 Polbud (n 3), paras 52-56.

${ }^{41}$ Case C-106/16 Polbud (n 3), para 55.

42 ibid paras 52,56 .

${ }^{43}$ Case C-378/10 VALE (n 4), para 40; by analogy, see Case C-411/03 SEVIC Systems AG (n 42), para 30.

${ }^{44}$ Case C-106/16 Polbud (n 3), paras 58-59.

45 ibid para 58.

${ }^{46}$ V Korom, P Metzinger, 'Freedom of Establishment for Companies: the European Court of Justice Confirms and Refines its Daily Mail Decision in the Cartesio Case C-210/06’ (2009) 6 European Company and Financial Law Review 125, 154-155.
} 
from a conversion in the host state 'to the extent that it is permitted under that law to do so'. ${ }^{47}$ One might wonder whether the host state enjoys full autonomy and can regulate cross-border conversions at its discretion. That question was clarified by the CJEU in the Vale case, where it ruled that its judgement in Cartesio does not mean that the national law on conversions is excluded from the scope of the provisions on the freedom of establishment, but rather demonstrates that:

'the mere consideration that a company established in accordance with national law exists only on the basis of the national legislation which 'permits' the incorporation of the company, provided the conditions laid down to that effect are satisfied'. ${ }^{48}$

Linking back to the previous discussion, the Member State has thus the right to, of course, determine the rules applicable to companies, including the connecting factors required for incorporation of the company and subsequently maintaining its status in its national jurisdiction. ${ }^{49}$ The autonomy of the Member States in this regard is not impinged on by the obligation to permit cross-border conversions. ${ }^{50}$ If the company intends to be converted in another jurisdiction it is for the host state alone to define what conditions should be met. It follows from the judgment in Polbud that a company has the right to convert itself in the host state provided that the company met all necessary conditions of the national law of that state, including national requirements on connecting factors. ${ }^{51}$ Accordingly, the question is not whether the national law permits a cross-border conversion, but what the conditions of domestic law are for a conversion of a foreign company, and whether the company is satisfying all necessary conditions, including the requirement on connecting factors.

Along with that, the host state does not have the right to refuse a conversion on the ground that national rules provide an opportunity to convert only for domestic companies. Such a difference in treatment for cross-border conversions of foreign companies amounts to a restriction on the freedom of establishment. ${ }^{52}$ If conversion is possible for domestic companies, the same possibility should be provided for a foreign company which intends to convert itself in the host state. ${ }^{53}$ Accordingly, the provisions on the freedom of establishment guarantee equal treatment of foreign and domestic companies in the host state. ${ }^{54}$

The host state has the right to determine the national law applicable to crossborder transactions and apply the national law for incorporation and operation of companies. ${ }^{55}$ Therefore, substantive rules which regulate domestic conversions can be applied to cross-border operations as well. Such rules should not be less favourable

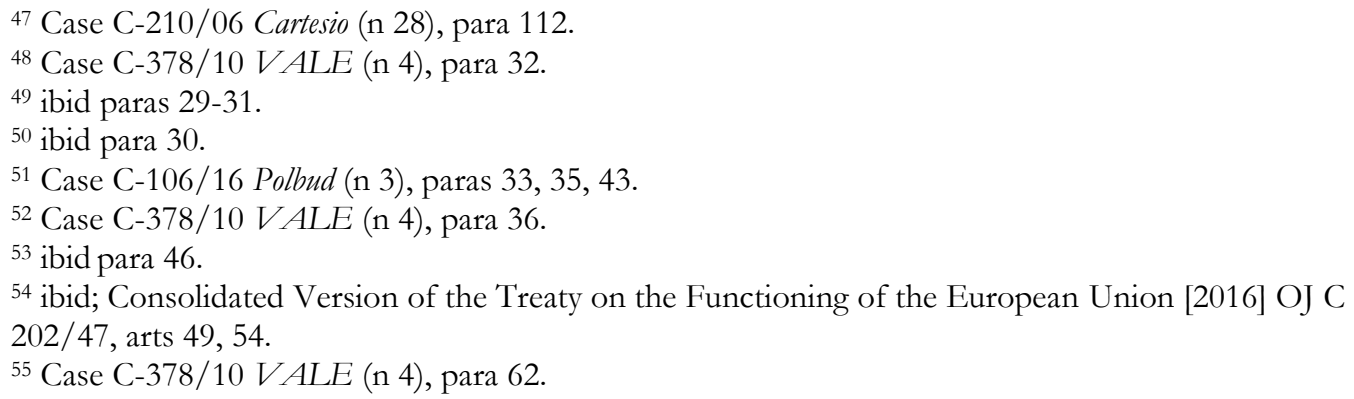


than those applicable to domestic transactions (principle of equivalence) and they should not make such transactions impossible in practice or it should not be excessively difficult to implement them (principle of effectiveness). ${ }^{56}$ The principle of equivalence will be breached if the host state provides specific opportunities for domestic transaction (such as record data in the register that a company is a predecessor in law to a converted company), but not in the case of cross-border transactions. ${ }^{57}$ The refusal of the host state to take into account documents, obtained from the home state, in order to be sure that a company complied with all its requirements and is disconnected with the law of the home state, is contrary to the principle of effectiveness. ${ }^{58}$ The rejection of such documents deprives a company of the opportunity to demonstrate that it fulfilled all conditions in the home state and puts the transaction at risk. ${ }^{59}$

Based on the case law it can be summarised that the host state has the power to define connecting factors, location of which within its territory is required for crossborder conversions. All connecting factors (the registered office, the central administration and the principal place of business) are placed on an equal footing in this regard. ${ }^{60}$ It is up to the host state to define which factor that serves as a link between a company and its national legal order, as well as what should be transferred to its territory for obtaining the status of a domestic company under its jurisdiction. This area enjoys immunity from the provisions on the freedom of establishment and companies have to comply with it. Along with that, the host state is empowered to define what national rules should be applied to cross-border conversions. It may apply rules, governing conversions of domestic companies, provided that such an application is in line with the principles of effectiveness and equivalence.

When comparing the respective powers of the home and the host state to determine the connecting factor, required for obtaining and maintaining the legal personality of the company, the following picture emerges: only rules of the host state enjoy immunity from the provisions on the freedom of establishment in case of crossborder conversions.

\section{NATIONAL LEGAL FRAMEWORKS AND POSSIBLE OBSTACLES TO CROSS-BORDER CONVERSIONS}

Despite the case law of the CJEU, some Member States prohibit the exit step in cross-border conversions, whilst in others it is unclear exactly how such operations are regulated in law, or dealt with in practice. ${ }^{61}$ Some Member States do not have any

\footnotetext{
56 ibid paras 48, 54 .

57 ibid paras 56, 57 .

58 ibid paras 58-61.

59 ibid para 60.

${ }^{60}$ Case 81/87 Daily Mail (n 25), paras 19-21; Case C-106/16 Polbud (n 3), para 34.

${ }^{61}$ C Gerner-Beuerle, F Mucciarelli, E Schuster, M Siems (n 9), 20-25. On a detailed description of how the home states treat the outbound step of a cross-border conversion, see Study on the law applicable to companies (n 9), 223-235; T. Papadopoulos 'Reincorporations: A Comparison between Greek and Cyprus law' (2018) 61 International Journal of Law and Management 901, 903-914. On the transfer of the registered office see T Biermeyer, M Meyer, 'Cross-border Corporate Mobility in the
} 
provisions that allow or regulate the inbound step of cross-border conversions. ${ }^{6}$ In the latter case, due to the absence of such operations in law, it is not clear whether they are possible in practice or how they are regulated in fact. Although, even in the absence of domestic law in the matter, scholars tend to consider cross-border conversions as possible based on the case law of the CJEU. ${ }^{63}$ However, such a prediction is insufficient to understand the real state of affairs regarding the status of cross-border operations. Moreover, even if cross-border conversions are explicitly permitted by law, or implicitly allowed in fact, the lack of procedural rules complicates or hinders the implementation of such operations. In the absence of procedural rules, the competent officials/authorities $^{64}$ may lack sufficient understanding of how cross-border conversions should be carried out. Equally, the concerned companies may lack information on what actions are required. This complexity might prevent companies from conducting cross-border conversions.

Since a conversion is of cross-border nature (ie, involving two states), the implementation of such an operation will be successful only if the home and the host state cooperate. Such cooperation is vital for maintaining continuity of a company's legal personality, which is one of the integral features of cross-border conversions. It is important to define the exact stage when a company has to be removed from the register in the home state and when the respective data has to be recorded in the register in the host state respectively. ${ }^{65}$ The outcome in the home state should be based on what was achieved in the host state. ${ }^{66}$ Therefore, a conversion should take effect on the date when it was registered in the host state and included in its register. ${ }^{67}$ After the registration in the host state the company has to be removed from the register of the home state. Ideally, this interaction between the two states should not entail any delays in entering the required data in the registers.

However, the absence of coordination between the home and host state may prevent successful consummation of a conversion and cause negative consequences. If a company is removed from the register of the home state before its registration in the host state it results in a situation where a company is registered nowhere. ${ }^{68}$ For instance, in the Vale case, VALE Costruzioni Srl, a company duly incorporated in Italy,

EU. Empirical findings 2017’ (2018) (Empirical findings 2017)

$<$ https://papers.ssrn.com/sol3/papers.cfm?abstract_id=3116042> accessed 13 July 2018, 25-29.

${ }^{62}$ C Gerner-Beuerle, F Mucciarelli, E Schuster, M Siems (n 9), 27-29. On a detailed description of how the host states treat the inbound step of a cross-border conversion see Study on the law applicable to companies (n 9), 240-247; T. Papadopoulos (n 61), 903-914. On the transfer of the registered office see Empirical findings 2017 (n 61), 25-29.

${ }^{63}$ C Gerner-Beuerle, F Mucciarelli, E Schuster, M Siems (n 9), 28-30; Study report on the law applicable to companies (n 9), 248.

${ }^{64}$ ie the officials/authorities which are competent to certify cross-border conversions and to register the respective data (notaries, registrars, courts, etc.).

${ }^{65}$ Study report on the law applicable to companies (n 9), 222; 238.

${ }^{66}$ By analogy, J Rickford, 'Current Development in European Law on Restructuring of Companies: An introduction' (2004) 15 European Business Law Review 1225, 1232.

${ }^{67}$ European Parliament resolution (2008/2196(INI)) (n 10), Recommendation 1; European Parliament resolution with recommendations to the Commission on a 14th company law directive on the cross-border transfer of company seats (2011/2046(INI)) of 2 February 2012 (European Parliament resolution (2011/2046(INI)), Recommendation 2, para 3.

${ }^{68}$ Study on the law applicable to companies (n 9), 222; C Gerner-Beuerle, F Mucciarelli, E Schuster, M Siems (n 9), 16-17. 
was removed from the Italian register due to its conversion into VALE Épitési kft, a company governed by Hungarian law. The refusal of Hungary to register the company gave rise to a situation where VALE was not a company under Italian law anymore and not yet a company under Hungarian law. During this period the status of the company was uncertain and AG Jääskinen raised a series of questions in this regard, such as who owns the company's assets, or who is responsible for the company's obligations before third parties? ${ }^{69}$ Other important questions arise in such situations, such as, what law regulates the relations between the company's constituencies?

When a company is not registered in any register, the existence of that company during that period may be questionable. ${ }^{70}$ In fact, the company may not be subject to any legal regime, resulting in possible opportunistic behaviour at the expense of vulnerable constituencies such as minority shareholders, employees and creditors. ${ }^{71}$ Moreover, a situation may occur where a company does not have the status of a domestic company in any jurisdiction. For instance, in the Interedil case, where an Italian company, which transferred its registered office to London, was removed from the Italian register of companies and included in the United Kingdom (UK) register of companies as a foreign company. ${ }^{72}$ Such non-coordinated actions of the Member States resulted in a situation where in Italy the company was considered as an English company and as an Italian in the UK. ${ }^{73}$ This means that for both countries the company had the status of a foreign company, but nowhere it was recorded as a domestic company. ${ }^{74}$ A question which arises here is which country's corporate law should govern the company? Let us consider another scenario: what would be the consequence if a company after consummation of a cross-border conversion is not removed from the register of the home state and is included in the register of the host state? Here, the same company is still a domestic company under the law of the home state, but in addition a domestic company under the law of the host state. What law should apply and how should the relations between constituencies of that company be regulated?

Such problematic situations illustrates why a common legal framework, coordinating actions of the home and host state, is necessary. It is important to pay attention not only to the specific moment when required data is entered in the register in the host state and removed from the register in the home state, but also what status a company obtains as a result of cross-border conversion.

Another aspect which may affect a cross-border conversion is the concept of seat. Diversity in the national laws of the Member States result in differences regarding connecting factors. That leads to the question of what a company is required to transfer under the national law for the purpose of conversion in the host state. Article 54 of the Treaty on the Functioning of the European Union (TFEU) defines the connecting

\footnotetext{
${ }^{69}$ Opinion of AG Jääskinen (n 7), paras 43-45.

${ }^{70}$ Study on the law applicable to companies (n 9), 222.

71 ibid.

${ }^{72}$ Case C-396/09 Interedil Srl, in liquidation v Fallimento Interedil Srl and Intesa Gestione Crediti SpA [2011] ECR I-09915, para 10.

${ }^{73}$ Study on the law applicable to companies (n 9), 238-239.

${ }^{74}$ ibid.
} 
factors as the registered office, the central administration and the principal place of business, however that list is not exhaustive and the national legal orders have more options. For instance, some Member States use the term of statutory seat which means a company's seat as stated in its charter. ${ }^{75}$ The stautory seat can be the registered office as well, however, both seats do not necessarily coincide. ${ }^{76}$ If the statutory seat is different from the registered office, a change of the statutory seat may not lead to a change of the registered office and consequently to a change of the applicable law. ${ }^{77}$ However, there are legal entities which are not subject to registration in the Member States, and these entities are not excluded from the scope of the freedom of establishment. ${ }^{78}$ Here, a question arises as to what such a legal entity should transfer in order to be allowed to convert itself in another jurisdiction?

The concept of the real seat is more divergent ${ }^{79}$ and identification of its location is an uneasy task in modern technological life. ${ }^{80}$ The possibilty to govern the company, to interact, meet and take decisions remotely through electronic means of communication may make it difficult to define where the real seat of the company is located. ${ }^{81}$

The understanding of what type of seat was transfered by the company to the host state is vital for defining the consequences of such transfer. For instance, there was a misunderstanding regarding what was relocated in the Cartesio case: the registered office or the real seat ${ }^{82}$ The reference for a preliminary ruling in its English version concerned the transfer of the registered office. ${ }^{83}$ AG Poiares Maduro considered the transfer of the operational headquarters. ${ }^{84}$ Based on this Ireland asked the CJEU to reopen the oral procedure. ${ }^{85}$ The CJEU indicated that the case concerned the transfer of the real seat. ${ }^{86}$ Interstingly, the company's seat under Hungarian law was the place where the company's central administration was located, but it should coincide with

\footnotetext{
75 ibid 221.

76 ibid.

77 ibid; C Gerner-Beuerle, F Mucciarelli, E Schuster, M Siems (n 9), 4-5.

${ }^{78}$ For instance, German Gesellschaft bürgerlichen Rechts. See Policy Department for Citizens' Rights and Constitutional Affairs (n 16), 34-35.

${ }^{79}$ Impact assessment 2007 (n 14), 42; Study report on the law applicable to companies (n 9), 119-127.

${ }^{80}$ S Lombardo, 'Conflict of Law Rules in Company Law after Überseering: An Economic and Comparative Analysis of the Allocation of Policy Competence in the European Union' (2003) 4 European Business Organization Law Review 301, 309-310; J Borg-Barthet, 'A New Approach to the Governing Law of Companies in the EU: A Legislative Proposal' (2010) 6 Journal of Private International Law 589, 617-618; K Sorensen, M Neville, 'Corporate Migration in the European Union' (2000) 6 Columbia Journal of European Law 181, 184-185; J Armour, H Fleischer, V Knapp, M Winner, 'Brexit and Corporate Citizenship' (2017) 18 European Business Organization Law Review 225, 236.

81 ibid.

${ }^{82}$ V Korom, P Metzinger (n 46), 134-136.

83 Official Journal of the European Union C 165 of 15 July 2006, 18

< http://eur-lex.europa.eu/LexUriServ/LexUriServ.do?uri=OJ:C:2006:165:0017:0018:EN:PDF> accessed 17 July 2018.

${ }^{84}$ Case C-210/06 Cartesio Oktató és Szolgáltató bt [2008] ECR I-09641, Opinion of AG Poiares Maduro, paras 1, 3, 23, 36 .

${ }^{85}$ Case C-210/06 Cartesio (n 28), paras 43-45.

86 ibid paras 47-50, 101.
} 
the registered office. ${ }^{87}$ Thus, when the national law contains the term 'seat' it might not be obvious whether it refers to the registered office or the real seat. ${ }^{88}$

Such inconsistency may cause difficulties for the successful implementation of a cross-border conversion, since it depends on what type of seat is transferred. Lack of understanding, or misunderstanding, of what was transferred or what should be transferred may give rise to false analyses, and consequently affect cross-border conversion where a company has to comply with the test on connecting factors in the host state.

\section{CONCLUSION}

The analysed case law confirms that cross-border conversions are covered by the freedom of establishment, provided that the requirements of the host state, including the test on connecting factors, are satisfied. The test on connecting factors may be considered as a reserved area of the host state where the home state loses its absolute power. In the current situation of EU law where no uniform legal framework is established, it is for the Member States to provide the opportunity for companies to carry out cross-border conversions.

Cross-border conversions may be considered as an achievement of the CJEU since its case law paves the way towards acceptance of such operations in all Member States. The CJEU clarified the scope of the freedom of establishment regarding crossborder conversion in the Polbud case. That judgment should give an impulse to those Member States whose law remains silent on the issue, lacks regulation or is not in line with the provisions on the freedom of establishment, to take appropriate legislative measures. However, that may not be sufficient in the current situation, where the laws of the Member States vary significantly. It should be acknowledged that a uniform legal framework at the European level is better than 28 divergent legal regimes, which are likely to result in various barriers to cross-border conversions. The lack of common rules on coordination between the home and the host state may result in a situation where a company is registered as a domestic company in the home and the host state simultaneously or is registered nowhere. The absence of an acceptable level of constituencies protection at the European level may lead to the imposition of burdensome requirements by the Member States. Therefore, a creation of a legal framework at the European level is needed to provide a commonly-accepted procedure for such operations, to secure protection for vulnerable constituencies, prevent abusive practices and to regulate cooperation between the states which are involved in cross-border conversions. Furthermore, a reconciliation of the concept of

\footnotetext{
87 Case C-210/06 Cartesio (n 28), para 101; V Korom, P Metzinger (n 46), 135, 142.

88 This is also the case in Poland which followed the real seat theory before joining the EU and the term 'seat' was perceived as the real seat, but now due to the case law of the CJEU, Poland is considered as a country which follows the theory of incorporation; it is also considered that no change occurred. See A Mucha, 'New Chapter in the Corporate Mobility in Europe - Some Remarks on the Polish Supreme Court Request for a Preliminary Ruling on the Outbound Limited Company Seat Transfer in the case C-106/16 Polbud-Wykonastwo' (2017) Allerhand Working Paper 20/2017, 8 $<$ https://ssrn.com/abstract=2954639 $>$ accessed 17 July 2018; Study on the law applicable to companies (n 9), 124-125.
} 
seat could bring more clarity regarding connecting factors and facilitate cross-border conversions.

The Commission submitted a Proposal for a Directive amending Directive (EU) 2017/1132 as regards cross-border conversions, mergers and divisions on 25 April 2018, but whether it will be adopted in the same version and when remains to be seen. If a proposed directive is adopted in the version it is submitted by the Commission, a legal framework will be created only for limited liability companies. ${ }^{89}$ According to the case law all companies and firms, which are formed in one of the Member States and have the registered office, the central administration or the principal place of business within the EU, may benefit from the freedom of establishment and have the right to conduct cross-border conversions. If that directive is adopted, the Member States may prohibit cross-border conversions, initiated by legal entities which have the right to convert, but are excluded from the scope of the directive, unless the issue is considered by the CJEU. However, the absence of secondary law in the EU should not result in an unenforceability of the provisions on the freedom of establishment, meaning that the limited scope of the proposed directive may not be a ground for prohibition of cross-border conversions.

\footnotetext{
89 Proposal for a Directive (n 6), art 86 (a). The scope of the proposed directive in regard to crossborder conversions was defined by analogy with cross-border mergers. It was explained that only limited liability companies are within the scope of a Proposal for a Directive due to little use of crossborder mergers by other types of legal entities (such as partnerships, cooperatives, foundations) and due to possible difficulties concerning EU company law and accounting rules since they cover only limited liability companies. See Commission Staff Working Document 'Impact Assessment accompanying the document Proposal for a Directive of the European Parliament and of the Council amending Directive (EU) 2017/1132 as regards the use of digital tools and processes in company law and Proposal for a Directive of the European Parliament and of the Council amending Directive (EU) 2017/1132 as regards cross-border conversions, mergers and divisions' SWD (2018) 141 final, 54; Proposal for a Directive (n 6), 18.
} 